\title{
Peningkatan Kualitas dan Produktivitas Produk Pengecoran Logam dengan Penataan Ulang Fasilitas Produksi
}

\author{
Hery Murnawan \\ Universitas 17 Agustus 1945 Surabaya
}

\author{
Nurani Hartik \\ Universitas 17 Aguatus 1945 Surabaya
}

\author{
Putu Eka Dewi Karunia Wati \\ Universitas 17 Aguatus 1945 Surabaya
}

\begin{abstract}
Changes in the market conditions make SMEs Metal Casting change the products produced. Changes in manufactured products are followed by the type of mold used. Initially, these SMEs only use the metal mold but currently required soil mold to create new products. With the addition of the type of mold used, there are some constraints on the metal molding process. The laying of soil mold away from the furnace makes the metal viscosity different from one product to another. To reduce the number of defects in production, it is necessary to rearrange the facility. The facility rearrangement starts from making a process operation map for each product up to the calculation of total productmoment count using From to Chart (FTC). By doing several experiments, then obtained a proposal layout that produces the total moment of the smallest product and the amount of output more than ever. So it can be said that the layout can improve the quality and productivity of SMEs metal casting.
\end{abstract}

Keywords: Facility Rearrangement; Productivity; Quality

\begin{abstract}
Abstrak
Perubahan kondisi pasar membuat UKM pengecoran logam mengubah produk yang diproduksi. Perubahan produk yang diproduksi diikuti dengan jenis cetakan yang digunakan. Awalnya, UKM ini hanya menggunakan cetakan logam, tetapi saat ini diperlukan cetakan tanah untuk membuat produk yang baru. Dengan penambahan jenis cetakan yang digunakan, terdapat beberapa kendala pada proses pencetakan logam. Peletakan cetakan tanah yang jauh dari tungku membuat kekentalan logam berbeda antara produk satu dengan yang lainnya. Untuk mengurangi jumlah kecacatan hasil produksi, perlu dilakukan penataan ulang fasilitas. Penataan ulang fasilitas dimulai dari pembuatan peta proses operasi untuk setiap produk sampai dengan perhitungan-perhitungan total momen produk dengan menggunakan From to Chart (FTC). Dengan melakukan beberapa kali percobaan, maka diperoleh sebuah layout usulan yang menghasilkan total momen produk terkecil dan jumlah output lebih banyak dari sebelumnya. Sehingga, dapat dikatakan bahwa layout tersebut dapat meningkatkan kualitas dan produktivitas UKM pengecoran logam.
\end{abstract}

Kata Kunci: Penataan Ulang Fasilitas; Peningkatan Kualitas dan Produktivitas; UKM Pengecoran Logam

\section{Pendahuluan}

Tata letak fasilitas merupakan sebuah kegiatan analisis penempatan fasilitas guna memperlancar proses produksi dan meningkatkan kualitas produksi (Apple \& Mardiono, 1990; Hadiguna \& Setiawan, 2008). Perancangan tata letak fasilitas yang baik akan berpengaruh terhadap pola aliran barang di dalam fasilitas tersebut (Wignjosoebroto, 1990). Pola aliran yang efisien adalah pola aliran yang dapat meminimumkan biaya produksi namun meningkatkan jumah output produksi. Melihat beberapa pengaruh pola aliran tersebut, beberapa penelitian dilakukan untuk mengefisienkan pola aliran dengan melihat total momen produk terkecil. Seperti penelitian yang dilakukan oleh Yuliant dkk. (2014) yang melakukan perancangan ulang fasilitas dengan memperhatikan pola aliran barang untuk menghasilkan ongkos material handling $(\mathrm{OMH})$ yang minimum. Hal yang sama juga dilakukan oleh Sofyan \& Syarifuddin (2018) yang 
merancang fasilitas kerja dengan menggunakan metode konvensional dengan mempertimbangkan 5S dan menghitung ongkos material handling setiap pola aliran barang untuk setiap produknya. Berdasarkan penelitian tersebut, penelitian ini mencoba menggunakan metode konvensional untuk meningkatkan kualitas dan produktivitas dilihat dari jumlah output yang dihasilkan dengan memilih pola aliran barang terkecil sesuai dengan permasalahan yang terdapat di salah satu UKM pengecoran logam.

CV Cahaya Mulia adalah sebuah UKM (Usaha Kecil Menengah) yang berada di Desa Domas RT 3 RW 1, Kecamatan Menganti, Kabupaten Gresik. UKM ini awalnya membuat wajan aluminium. Seiring dengan berkurangnya permintaan, terjadi pergeseran pembuatan komponen dari aluminium yang dilakukan dengan proses pengecoran logam aluminium. Proses pengecoran logam ini menggunakan cetakan dari tanah dan logam (besi) dengan hasil produksi seperti puli diesel, puli bubut bulu ayam, baut kupingan, baling-baling perahu, dan tutup oli. Perubahan hasil produksi yang awalnya wajan berganti komponen untuk permesinan dari aluminium membuat alur proses produksinya berubah.

Pembuatan komponen aluminium yang menggunakan cetakan tanah membutuhkan ruang yang lebih luas dalam proses pengecoran logam aluminium dibandingan dengan cetakan logam (besi). Pemilik CV Cahaya Mulia tidak memikirkan bahwa perubahan proses produksi akan berakibat pada perubahan alur proses yang pada akhirnya akan berdampak pada produktivitas kerja, yaitu hasil atau output produksinya tidak bisa maksimal.

Pada pengamatan awal yang dilakukan pada UKM CV Cahaya Mulia, terlihat bahwa terdapat perpindahan jarak dari tungku peleburan menuju proses cetakan tanah yang cukup jauh. Hal tersebut dapat mengakibatkan penurunan suhu cairan aluminium yang berimbas pada proses pengentalan cairan dan tingkat kepadatan hasil cetakan sehingga hasil produksinya akan lebih berat atau memakan jumlah material yang lebih banyak. Sementara itu, penjualan yang dilakukan oleh pemilik CV Cahaya Mulia didasarkan harga per satuan unit. Bila hal tersebut terjadi maka akan terjadi kerugian atau akan dilakukan proses daur ulang (recycle) terhadap produk yang beratnya melebihi standar.

Alur proses produksi pengecoran logam aluminium dengan menggunakan cetakan tanah maupun cetakan logam untuk menghasilkan komponen logam aluminium dapat digambarkan pada layout awal, yaitu berawal dari tungku peleburan yang kemudian dituang dalam cetakan tanah maupun cetakan logam. Kemudian, dilakukan proses pada mesin bubut dan drilling maupun gerinda. Kendala yang dihadapi oleh CV Cahaya Mulia yang mengubah hasil produksi dari wajan ke produk komponen dari aluminium berakibat pada berubahnya alur proses produksi. Guna melakukan penataan terhadap ruang produksi untuk disesuaikan dengan alur proses produksi yang baru, yaitu komponen dari aluminium, dilakukan penataan fasilitas produksi (layout). Penataan fasilitas produksi ini dilakukan dengan memperhatikan kapasitas produksi setiap produk dan jarak perpindahan pada setiap tahapan prosesnya. Penataan fasilitas produksi ini diharapan akan mampu menunjang proses produksi yang efisien yang pada akhirnya dapat meningkatkan produktivitas kerja.

\section{Metode Pelaksanaan}

Pelaksanaan pengabdian kepada masyarakat (PKM) dilakukan dengan mengamati alur proses pengecoran logam dengan cetakan tanah dan logam (besi). Alur proses tersebut kemudian digambarkan dalam bentuk peta proses operasi (Operation Process Chart [OPC]) dari setiap produk yang diamati. Peta proses operasi ini akan memberikan gambaran fasilitas kerja yang digunakan dalam proses produksi dan tingkat kecacatan setiap tahapan proses serta waktu yang dibutuhkan dari setiap proses. Kapasitas produksi setiap produk akan ditentukan berdasarkan jumlah permintaan kemudian akan dihitung jumlah kebutuhan bahan baku berdasarkan tingkat kecacatan pada setiap tahapan proses. Setelah menghitung total produk dalam setiap proses, dilakukan perhitungan jumlah mesin. Perhitungan jumlah mesin dilakukan dengan persamaan: 
dengan

$$
N=\frac{T}{60} \times \frac{P}{D \cdot E}
$$

$\mathrm{P}=$ jumlah produk yang harus dibuat oleh masing-masing mesin per periode waktu kerja (unit produk/tahun),

$\mathrm{T}=$ total waktu pengerjaan yang dibutuhkan untuk proses operasi produksi yang diperoleh dari hasil time study atau perhitungan secara teoretis (menit/unit produk),

$\mathrm{D}=$ jam operasi kerja mesin yang tersedia,

$\mathrm{E}=$ faktor efisiensi kerja mesin yang disebabkan oleh adanya set up, break down, repair, atau hal-hal lain yang menyebabkan terjadinya idle (kisaran nilai $=0,8-0,9$ ), serta

$\mathrm{N}=$ jumlah mesin ataupun operator yang dibutuhkan untuk operasi produksi.

Setelah menghitung total produk dalam setiap proses, dilakukan perhitungan jumlah mesin. Jumlah mesin yang dibutuhkan pada setiap tahapan proses kemudian digambarkan dalam Multi Part Proces Chart (MPPC). Selanjutnya, dibuat Activity Relationship Chart (ARC) yang menunjukan hubungan kepentingan antardepartemen produksi. Langkah selanjutnya yaitu menghitung kebutuhan luas area produksi yang dibutuhkan dan membuat tata letak awal berdasar ARC kemudian melakukan perhitungan aliran material antardepartemen dalam proses produksi. Hasil dari besarnya bobot aliran material dalam departemen kemudian dihitung dengan menggunakan metode From To Chart (FTC) untuk mendapatkan nilai backward yang minimum untuk dapat dijadikan sebagai layout pilihan. Masing-masing alternatif pilihan layout akan dihitung kapasitas produksinya untuk mengetahui efisiensi dari alur proses produksi pada saat penataan layout sehingga dapat dihitung besarnya produkstivitas yang dihasilkan.

\section{Hasil dan Pembahasan}

Berdasarkan pengukuran luas lokasi, diketahui bahwa luas ukuran tanah yaitu $10 \times 15$ meter dengan gambar layout saat ini seperti yang terlihat pada Gambar 1.

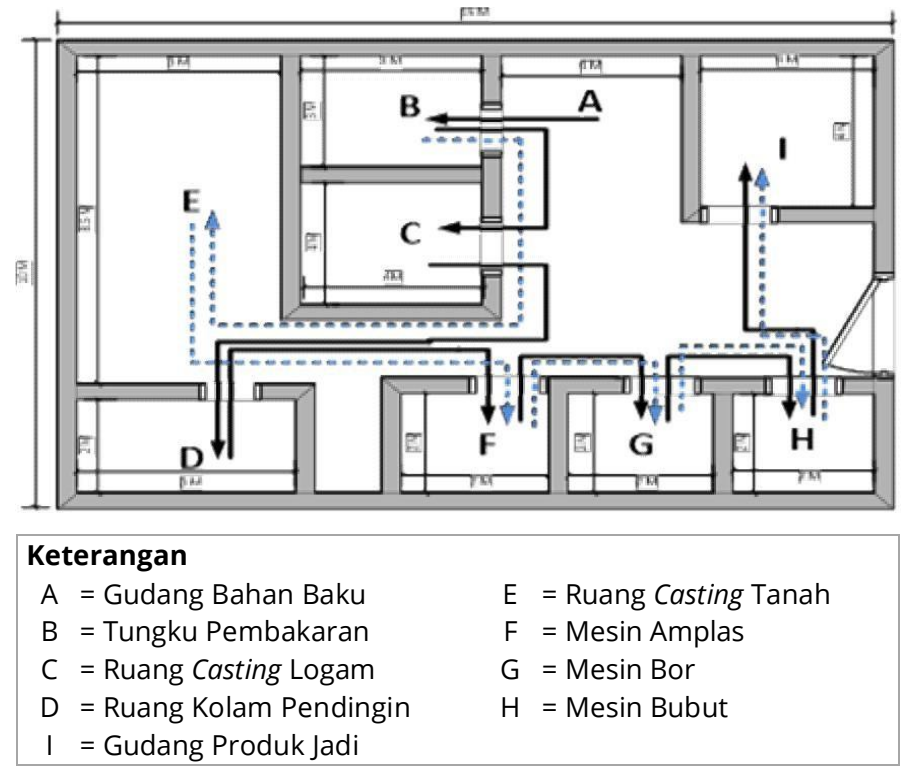

Gambar 1. Layout Awal Ruang Produksi 


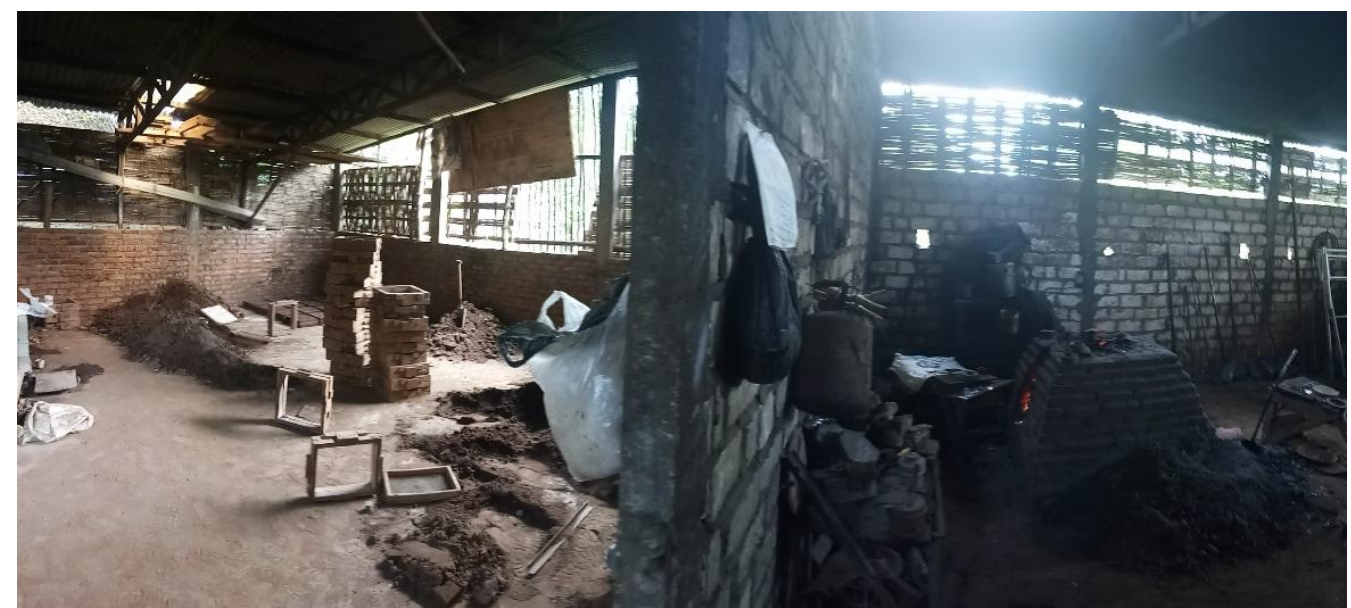

Gambar 2. Kondisi Ruang Produksi Awal

Pada Gambar 1, dapat dilihat pergerakan proses dari tungku pembakaran menuju area casting dengan menggunakan cetakan tanah cukup jauh. Untuk memperjelas berapa total momen pemindahan aliran produk, bantuan From To Chart dapat digunakan sehingga diketahui sejauh mana pergerakan produk untuk setiap proses. From To Chart dapat dibuat dengan menganalisis layout awal dengan mengetahui jarak dan hubungan antarmesin. Gambar 3 akan menjelaskan jarak dan hubungan antarmesin berdasarkan layout awal.

\begin{tabular}{|c|c|c|c|c|c|c|c|c|c|c|}
\hline $\begin{array}{l}\text { EROM } \\
\text { TO }\end{array}$ & A & B & C & D & E & $\mathrm{F}$ & G & $\mathrm{H}$ & I & TOTAL \\
\hline A & & & & & & & & & & 0,00 \\
\hline B & 827,0 & & & & & & & & & 827,04 \\
\hline C & & 356,7 & & & & & & & & 356,70 \\
\hline D & & & & & & & & & & 0,00 \\
\hline E & & 659,0 & & & & & & & & 658,95 \\
\hline $\mathrm{F}$ & & & & & 571,1 & & 92,7 & 239,4 & & 903,19 \\
\hline G & & & & & 184,4 & & & & & 184,40 \\
\hline $\mathrm{H}$ & & & & 475,6 & 263,5 & & & & & 739,10 \\
\hline I & & & & & & 536,4 & & 214,0 & & 750,41 \\
\hline & 827,0 & $1.016,0$ & 0,0 & 475,6 & $1.019,0$ & 536,4 & 92,7 & 453,4 & 0 & $4.419,79$ \\
\hline
\end{tabular}

\section{Keterangan}

$\mathrm{A}=$ Gudang bahan baku

$\mathrm{B}=$ Tungku Bakar

C = Ruang Pencetakan Logam
$\mathrm{D}=$ Kolam Pendingin

$\mathrm{E}=$ Ruang Pencitakan Tanah

$\mathrm{F}=$ Mesin Amplas
$\mathrm{G}=$ Mesin Bor

$\mathrm{H}=$ Mesin Bubut

$\mathrm{I}=$ Gudang Produk jadi

Gambar 3. Diagram From To Chart Berdasarkan Layout Awal 
Berdasarkan Gambar 3, dapat diketahui volume material berdasarkan jarak diagonal dan analisis momen untuk layout awal. Hasil perhitungan momen awal dapat dilihat pada Tabel 1.

Tabel 1. Perhitungan Total Momen dari Layout Awal

\begin{tabular}{llrl}
\hline Jarak Terhadap Diagonal & $\begin{array}{l}\text { Forward } \\
\text { (Distance from Diagonal) }\end{array}$ & $\begin{array}{l}\text { Backward } \\
\text { (Distance from Diagonal) }\end{array}$ \\
\hline 1 & $2.563,3$ & 185,4 \\
2 & 368,8 & 957,6 \\
3 & $4.376,5$ & 0,0 \\
4 & $1.902,4$ & 0,0 \\
5 & 0,0 & 0,0 \\
& 0,0 & 0,0 \\
TOTAL & 0,0 & 0,0 \\
\hline
\end{tabular}

Berdasarkan Tabel 1, diketahui total momen produk seluruhnya yaitu dengan menambahkan total forward dan total backward yaitu sebesar 10.354. Nilai dari total momen tersebut yang akan dijadikan sebagai acuan untuk membuat sebuah layout yang dapat menghasilkan total momen produk yang lebih kecil dari nilai tersebut.

Untuk perhitungan total output yang dihasilkan, perbedaan mencolok adalah hasil dari penataan untuk area casting tanah. Luas area casting tanah adalah $25.500 \mathrm{~cm}^{2}$. Jumlah cetakan yang dapat ditampung dalam area casting tanah adalah sebanyak 20 cetakan. Setiap cetakan memiliki bentuk persegi dengan panjang sisi $30 \mathrm{~cm}$. Jarak 1 cetakan dengan cetakan yang lain adalah $5 \mathrm{~cm}$ sehingga untuk 1 cetakan membutuhkan luas dengan sisi $35 \mathrm{~cm}$. Untuk jumlah output yang dapat dihasilkan dengan menggunakan layout ini (awal) dapat dilihat pada Tabel 2.

Tabel 2. Total Output Masing-Masing Produk

\begin{tabular}{llrrr}
\hline No. Jenis Produk & $\begin{array}{l}\text { Jumlah yang Dicetak pada } \\
\text { 1 Cetakan Tanah }\end{array}$ & $\begin{array}{l}\text { Jumlah Cetakan dalam Ruang } \\
\text { Cetakan Tanah }\end{array}$ & Total \\
\hline 1 & Baut kupingan & 8 & 20 & 160 \\
2 & Puli bubut bulu ayam & 4 & 20 & 80 \\
3 & Tutup oli & 12 & 20 & 240 \\
\hline
\end{tabular}

Dapat dilihat pada Tabel 2, dengan menggunakan area sebesar $25.500 \mathrm{~cm}^{2}$ dapat dihasilkan produk baut kupingan sebanyak 160, puli bubut bulu ayam sebanyak 80, dan tutup oli sebanyak 240 buah.

Sebagai perbandingan, dilakukan beberapa kali trial untuk mengubah penataan atau layout fasilitas tersebut. Pada trial layout ini, dilakukan pemindahan keseluruhan ruang kecuali ruang mesin bor, bubut, dan amplas karena ketiganya sudah memiliki momen backward dengan nilai 0. Untuk mendapatkan momen forward yang paling minimum dan memperluas ruang casting tanah yang awalnya $8 \times 3,5 \mathrm{~m}$ menjadi $10 \times 4 \mathrm{~m}$ maka dilakukan trial layout seperti yang terlihat pada Gambar 4.

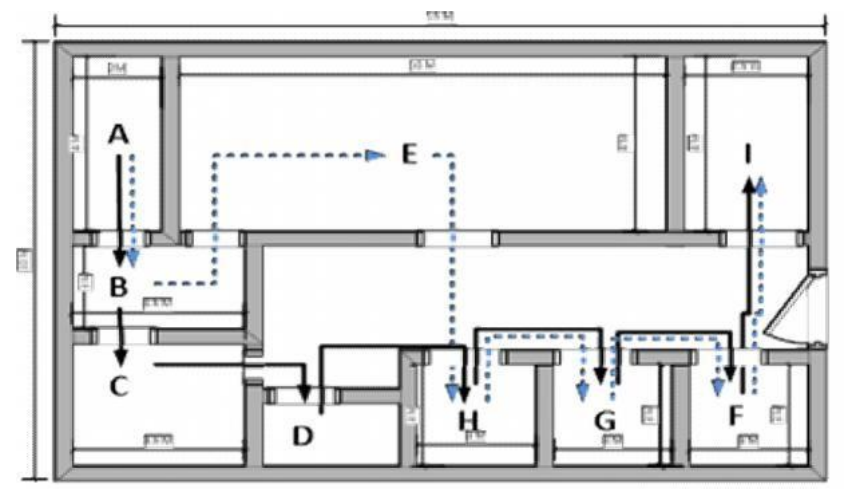

Gambar 4. Trial Layout 
Pada Gambar 4 dapat dilihat bahwa area yang didekatkan adalah tungku pembakaran dengan ruang casting tanah guna mengurangi momen produknya. Selain itu, area yang posisinya tetap yaitu area untuk mesin bor. Area tersebut tetap pada posisi awal dikarenakan tidak ada perubahan signifikan jika memindahkan area tersebut.

Cara yang sama dilakukan dengan metode From To Chart sehingga dapat diketahui volume material berdasarkan jarak diagonal dan analisis momen untuk trial layout. Hasil perhitungan total momen untuk trial layout dapat dilihat pada Tabel 3.

Tabel 3. Perhitungan Total Momen dari Trial Layout

\begin{tabular}{lrrr}
\hline Jarak Terhadap Diagonal & $\begin{array}{l}\text { Forward } \\
\text { (Distance from Diagonal) }\end{array}$ & $\begin{array}{l}\text { Backward } \\
\text { (Distance from Diagonal) }\end{array}$ \\
\hline 1 & $1.780,14$ & 0,00 \\
2 & 954,40 & 0,00 \\
3 & 379,80 & 0,00 \\
4 & $2.416,15$ & 0,00 \\
& 0,00 & 0,00 \\
& 6 & 0,00 & 0,00 \\
& 7 & 0,00 & 0,00 \\
\hline TOTAL & $6.946,49$ & 0,00 \\
\hline
\end{tabular}

Berdasarkan Tabel 3, diketahui total momen produk seluruhnya yaitu 6.949,49 yang hanya merupakan nilai momen produk forward dan nilai backward yang bernilai 0 . Nilai total momen produk tersebut jauh lebih kecil dari momen produk yang diperoleh berdasarkan layout awal dengan selisih mencapai 3.407,62. Nilai total momen produk untuk trial layout lebih kecil dibandingkan dengan menggunakan layout awal dikarenakan nilai backward-nya jauh lebih kecil yaitu 0. Dengan mengurangi backward sangat mempengaruhi nilai dari total moment produk.

Menggunakan trial layout maka dihitung kembali jumlah output yang dihasilkan. Dengan mengubah layout, maka luas area casting tanah juga berubah menjadi $40.000 \mathrm{~cm} 2$. Dengan menggunakan ukuran cetakan yang sama maka untuk 1 cetakan juga membutuhkan luas dengan sisi $35 \mathrm{~cm}$. Akan tetapi, dengan memperluas area casting tanah maka jumlah cetakan yang ditampung dalam area tersebut juga semakin banyak yaitu 32 cetakan. Untuk rician output yang diperoleh dengan merubah layout awal dapat dilihat pada Tabel 4.

Tabel 4. Total Output Masing-Masing Produk dengan Menggunakan Trial Layout

\begin{tabular}{llrrr}
\hline No. & Jenis Produk & $\begin{array}{l}\text { Jumlah yang Dicetak pada } \\
\text { 1 Cetakan Tanah }\end{array}$ & $\begin{array}{l}\text { Jumlah Cetakan dalam Ruang } \\
\text { Cetakan Tanah }\end{array}$ & Total \\
\hline 1 & Baut kupingan & 8 & 32 & 256 \\
2 & Puli bubut bulu ayam & 4 & 32 & 128 \\
3 & Tutup oli & 12 & 32 & 384 \\
\hline
\end{tabular}

Berdasarkan Tabel 4, diketahui jumlah output yang dihasilkan dengan menggunakan trial layout. Selanjutnya, untuk melihat perbandingan output yang dihasilkan untuk kedua jenis layout, dapat dilihat pada Tabel 5.

Tabel 5. Perbandingan output hasil cetakan tanah dengan layout awal dan trial layout

\begin{tabular}{llrrr}
\hline No. & Jenis Produk & \multicolumn{2}{c}{ Total Output } & \multirow{2}{*}{ Selisih } \\
\cline { 3 - 4 } & & Layout Awal & Trial Layout & \\
\hline 1 & Baut kupingan & 160 & 256 & 96 \\
2 & Puli bubut bulu ayam & 80 & 128 & 48 \\
3 & Tutup oli & 240 & 384 & 144 \\
\hline
\end{tabular}




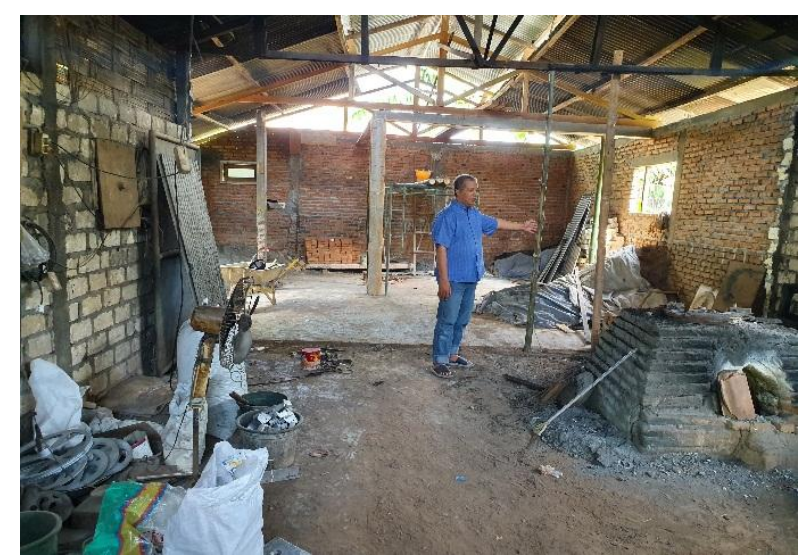

Gambar 5. Kegiatan Pengabdian Penataan Ruang Produksi Sebelum Tungku Peleburan Dipindah

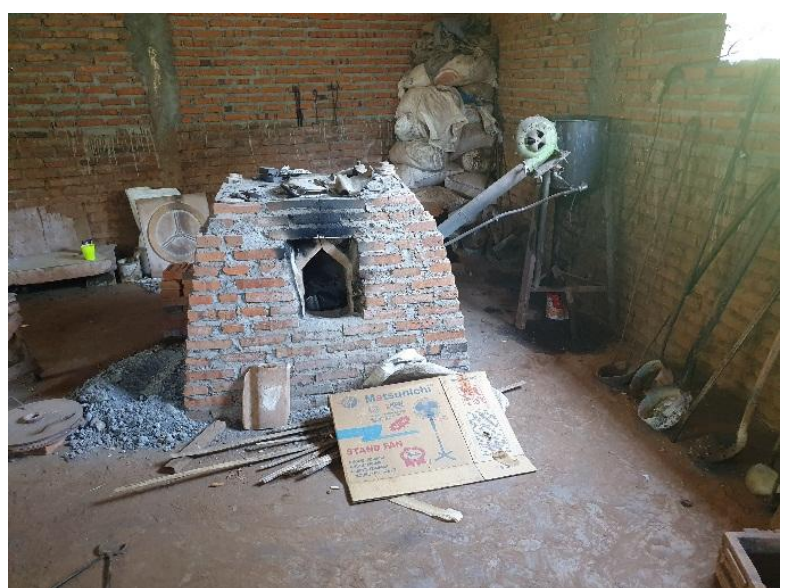

Gambar 6. Kegiatan Pengabdian Memindahkan Tungku Peleburan pada Ruang Belakang

Berdasarkan hasil yang diperoleh dengan membandingkan layout awal dan trial layout, layout yang menjadi layout usulan adalah trial layout. Trial layout tersebut dapat dikatakan meningkatkan produktivitas dilihat dari total momen produk yang dihasilkan dan output produksi yang dihasilkan yaitu dari 480 buah produk yang dihasilkan untuk satu area casting menjadi 768 buah. Selain dilihat dari output yang dihasilkan, peningkatan juga dapat dilihat dari total momen produknya. Semakin kecil total momen produk, semakin sedikit pula pemindahan material yang dilakukan sehingga dapat mengurangi gerak operator. Dengan demikian operator dapat bekerja secara efektif dan lebih cepat karena jarak yang saling berdekatan.

\section{Kesimpulan}

Berdasarkan hasil penelitian diperoleh nilai total momen produk layout awal lebih besar dibandingkan dengan trial layout. Sehingga, dapat dikatakan bahwa trial layout merupakan layout yang paling efektif untuk digunakan karena jarak perpindahan material lebih kecil dan volume produk yang dipindahkan semakin kecil.

\section{Ucapan Terima Kasih}

Ucapan terima kasih disampaikan kepada DRPM Ristekdikti yang telah memberikan dana hibah pengabdian kepada masyarakat dalam pelaksanaan kegiatan pengabdian di CV Cahaya Mulia sehingga dapat meningkatkan kualitas dan produktivitasnya yang pada akhirnya dapat meningkatkan pendapatan UKM pengecoran logam aluminium. 


\section{Daftar Pustaka}

Apple, J. M., \& Mardiono, N. M. (1990). Tata letak pabrik dan pemindahan bahan. Penerbit ITB.

Hadiguna, R. A., \& Setiawan, H. (2008). Tata Letak Pabrik. CV Andi Offset.

Sofyan, D. K., \& Syarifuddin, S. (2018). Perancangan Ulang Tata Letak Fasilitas dengan Menggunakan Metode Konvensional Berbasis 5s (Seiri, Seiton, Seiso, Seiketsu dan Shitsuke). Jurnal Teknovasi: Jurnal Teknik dan Inovasi, 2(2), 27-41.

Wignjosoebroto, S. (1990). Tata Letak Pabrik dan Pemindahan Bahan Edisi Ketiga. Penerbit Guna Widya.

Yuliant, R., Saleh, A., \& Bakar, A. (2014). Usulan Perancangan Tata Letak Fasilitas Perusahaan Garmen CV. X dengan Menggunakan Metode Konvensional. REKA INTEGRA, 2(3), Article 3. https://ejurnal.itenas.ac.id/index.php/rekaintegra/article/view/541

\section{Afiliasi:}

Hery Murnawan ${ }^{(\star)}$, Nurani Hartatik, Putu Eka Dewi Karunia Wati

Fakultas Teknik, Universitas 17 Agustus 1945 Surabaya

Jalan Semolowaru No. 45, Surabaya, Jawa Timur

E-mail : herymurnawan@untag-sby.ac.id $\left.{ }^{\star}\right)$,nuranihartatik@untag-sby.ac.id, putu_ekdkw@untag-sby.ac.id

URL : https://industri.untag-sby.ac.id 